\title{
2 SAM 14:16: STOP THE WICKED MAN ${ }^{1}$
}

\author{
Rudolph Oosthuizen \\ University of Fort Hare
}

\section{Abstract}

The renewed call for relevance in the so-called new South Africa renders possible an exciting new stage in the development of Old Testament scholarship. Reading the Bible (2 Sam 14:1-24) from a perspective informed by our own context, Africa, sheds new light on the understanding of the text and allows the biblical and African views of reality to interact in the process of interpretation. Old Testament scholarship needs to develop models of reading the Bible creatively and effectively in the South African (African) context.

\section{Introduction}

'Mr. Jones, of the Manor Farm, had locked the hen-houses for the night, but was too drunk to remember to shut the pop-holes. With the ring of light from his lantern dancing from side to side, he lurched across the yard, kicking off his boots at the back door, drew himself a last glass of beer from the barrel in the scullery, and made his way up to bed, where Mrs Jones was already snoring. As soon as the light in the bedroom went out there was a stirring and a fluttering all through the farm buildings. Word had gone round during the day that old Major, the prize Middle White boar, had a strange dream on the previous night and wished to communicate it to the other animals. It had been agreed that they should all meet in the big barn as soon as Mr. Jones was safely out of the way. Old Major (so he was always called, though the name under which he had been exhibited was Wellingdon Beauty) was so highly regarded on the farm that everyone was quite ready to lose an hour's sleep in order to hear what he had to say.' Animal Farm (George Orwell) (1945:5)

South Africa, like the rest of Africa, is going through a tremendous and rapid change in every aspect of human life. Many individuals are becoming increasingly detached from the corpus of their tribal and traditional beliefs, concepts, and practices (Mbiti 1970:xiv). South African society must reposition itself with regard to the socio-political, economical and ideological context wherein it finds itself since the dawning of a new era.

The dawning of a new South Africa ${ }^{2}$ literally brought about a fluttering in the various departments of biblical/religious studies and theological faculties in South Africa. Recent developments in South Africa, specifically the socio-economic and political changes currently taking place, resulted in a renewed debate concerning religious pluralism, tertiary

1. The title is that of a prayer of the Duala of Cameroun. At the time of the New Moon the prayer, a petition for protection from misfortune and from the machinations of wicked men, is recited (Shorter 1975:104). The wicked man in this discussion has many faces. It is the king who is himself guilty of not showing mercy to those closest to him, i.e. Absalom; Also, Joab, an ambitious man trying to advance his own position in the royal court. Absalom, who is a murderer of his own blood. But then also those who once again try to manipulate the Bible by submitting it to interpretative keys which in some way overlaps only formally with it, if at all.

2. South Africa, with its controversial history and complex population composition, returned to the international arena after the first democratic election on 27/28 April 1994, which resulted in the power of governance to be transferred from white minority rule to democratically elected majority rule. 
education and the status of religion, to name but a few aspects relevant to the current debate. ${ }^{3}$ Under the auspices of 'market related' courses, universities that need to move out from their 'ivory tower existence' and 'into the community' as well as the pressures of the financial implications of state subsidies for universities under the newly elected government, the call for relevance in the new South African context seems to dominate the debate regarding the future of Old Testament Studies.

The study of the Old Testament in South Africa was born in the cradle of European and American scholarship and to a large extent ignored the importance of doing theology from within the African context (Bosman 1990:54; Deist 1992:211; Hovland 1993:99). The results of such study were influenced by a Modern Enlightenment Paradigm which derives from and focuses on Western and European concepts (e.g. in philosophy), methodology (i.e. scientific investigation), technology (e.g. industrialization) and politics (e.g. democracy) (Kung 1986:10-14). Different presuppositions, foundational to world-views, lead to different interpretations of the Biblical text.

Materially, therefore, the study of the Old Testament has been strongly influenced by an individualistic Western approach (Hovland 1993:99):

Western theology has interpreted the Bible on the Basis of Greek and West-European experience, while African experience has not been given any place in theological reflection. It is important to redress this one-sideness lest Christian Theology becomes heretical.

Old Testament scholarship is in need of a contextual approach that takes cognisance of the cultures of the different peoples in South Africa. That would require that the worldviews informing these cultures be taken seriously and that an attempt be made to appreciate the importance of their function within the South African context, also for the interpretation of the Old Testament (Hindson 1984:33, own emphasis):

The social, economic, political and other contexts of texts as well as of interpreters have an important bearing upon the 'meaning' of such texts. Any interpreter should be conscious of this fact and inculcate it into his pronouncements on the 'meaning' of a text.

A contextual approach seeks to bring together the culture of the biblical world and the culture of today's readers of the bible (Moila 1992:119). In consequence, the interpretation of the bible should facilitate a true dialogue between the text and the contemporary reader. In so doing, I would like to contribute towards the development of a 'Theologia Africana' ${ }^{4}$

Various attempts at contextualization ${ }^{5}$ can be found in one form or another, i.e theologies of contextualization such as 'Black Theology' in Africa, 'Waterbuffalo Theology' in Asia and 'Liberation Theology' in America (Cole 1984:9). Although one can

3. The theme of the annual conference of the South African Biblical Studies Society for 1996, held in Bloemfontein, 17 \& 18 May 1996, was 'Interpreting the Bible for the New South Africa', which illustrated the attempts of Biblical Scholarship in South Africa to come to terms with the context wherein it finds itself, i.e. Africa.

4. The term 'Theologia Africana', which is Latin for African Theologies can be ascribed to Prof Harry Sawyer and appeared in published form for the first time in 1969 (Kwesi A Dickson, 'Towards a Theologia Africana', New Testament Christianity for Africa and the World, ME Glasswell and EW Fashole-Luke (eds), S.P.C.K., London, 1974, p. 206). Prefixed by the designation Christian (i.e. Christian African Theology) it is distinguished from African Theology not restricted to the biblical grounding (Wambutda 1980:30).

5. Contextualization is part of a wider theological concern for understanding the function of the church in the world (Nicholls 1979:22). 
identify some common concerns, amongst others the focus on 'praxis' and its analysis of conflict in South American liberation Theology and Black Theology, African Theology is to be distinguished from these in its positive assessment of its own African culture (Hovland 1993:91), while it seeks to reflect upon and express the Christian faith in African thoughtforms and idioms as it is experienced in African communities, and always in dialogue with the rest of Christendom (Kurewa 1975:36).

The epistomological foundation for 'African Theology' is the living religio-cultural heritage found in Africa (Hovland 1993:96). One important feature of the African world-view is the sense of community, the fact that the life of the individual human person finds meaning and explanation in terms of the structure of relationships within the human community (Ogbonnaya 1993:117; West 1993:3; Ukpong 1995:9). The African proverb 'Only the gathered fingers beat the drum' echoes this philosophy (Olson 1991:273). This 'sense of community' includes the living, the 'living-dead'6 and the unborn (Olson 1991:274; Oduyoye 1991:467). In fact, everything that concerns the family is of interest to the ancestors since they are its elders and will seek rebirth in the same family; the family land is their property (Parrinder 1962:59). This African tradition is the interlocutor for African Theology. A reading of the text, with specific reference to the account of the Tekoaite woman (2 Sam 14:1-24) in the 'Succession Narrative', from a perspective informed by our own context, Africa, sheds new light on the understanding of the text and allows the biblical and African views of reality to interact in the process of interpretation. Biblical scholarship in the past devoted most of its efforts to the literary analysis of these 'court histories' rather than the role of the people. i.e. social organization, political ideology and traditional political institutions (Tadmor 1982:239).

Two aspects in the account of the Tekoaite woman (1 Sam 14:1-24) that deserves special mention is the role of the ancestors (forefathers) in the fate of the family and the importance of the family land (ancestral land), both of which can be regarded as central to the African world-view and experiences of reality. In conjunction with Lewis (1991:600) the possibility of translating in 2 Sam 14:16 with 'ancestral estate' is investigated in its implications for a South African audience. It prompts interpreters to attribute alternative meanings to the text, meanings which are (co-) determined by our African context. Doing so 'opens up' the text to a South African audience and makes the reading more appropriate and comprehensible in a changing society like ours.

\section{An 'African theological' perspective on 2 Sam 14}

The text in question forms part of the narrative complex 2 Samuel 9-20 \& $1 \mathrm{King}$. 1-2, generally known as the 'Succession Narrative' in Old Testament scholarship since the work of Rost in 1926, i.e. 'Die Uberlieferung von der Thronnachfolge Davids' (Vriezen 1948:167; Brueggemann 1972:3; Ackroyd 1981:386; Fokkelman 1981:9; Vorster 1986:346). The acceptance of the existence of the so-called 'Succession Narrative', which contains information about the struggles for power in the court of David (Flanagan 1988:19), is the result of form-critical investigations (Vorster 1986:346). Whereas what precedes 2 Samuel 9 can be understood more in terms of the establishment of David's kingship (Ackroyd 1981:385), 2 Sam 9-24 describes the

6. The recently dead are known as the 'living-dead' as long as they are kept in remembrance, perhaps for as long as five to seven generations (Olson 1991:27). 
decline of David's rule (Fohrer 1968:222). After David's rise to power (1 Sam 16:14-2 Sam $5: 10)$ the story describes some of the events that marks the political turmoil that erupted in David's lifetime (McCarter 1981:356). Various narrative cycles depict the conflicts and detoriation in the 'house of David' (Deist 1981:84) which include the rebellion of Absolom (cf 2 Samuel 13-19). Fokkelman (1981:19) regards 2 Sam 13:39 - 14:24 as one of the 'scenes" in the narrative complex. In a 'juridical parable', (Gunn 1976:18), David is confronted by a well spoken Tekoaite woman (2 Samuel 14:1-24), a widow with great wisdom (cf Pr 10:20, 31), with a fictitious legal case (Spangenberg 1986:272).

In a quarrel the one son slew the other, and according to customary law, should be brought to justice (cf Dt 19:11-13; Num 35:16-18). In this case the clan wished to punish the remaining son in order to satisfy the rigid drive for familial justice (Coats 1981:382). The case against the one son would, however, determine the life-situation of the widow as well as the 'future' of the deceased husband (cf. 2 Sam 14:7). In the narrative two legal principles, justice and mercy, are in conflict with one another: should the family's claim be honored and blood-revenge be carried out or must the survival of the bet 'ab prevail over the old tribal law? (Fokkelman 1981:134; Coats 1981:378). Central to this narrative section is the Tekoaite woman's monologue in 2 Sam 14:12-17 (Fokkelman 1981:131) wherein she pleads for the 'gracious preservation' of herself and her son. The 'centrality' and importance of 2 Sam 14:12-17 is even more understandable in view of the role that ancestors and the ancestral inheritance (i.e. the land) played in ancient Israel (cf. 2 Sam $14: 7,16)$.

\subsection{The 'living dead' in the Old Testament}

The Old Testament refers to the deceased in a variety of ways, such as 'those who pass over (Ezek. 39:11-15), 'mutterers' (Isa. 19:3), 'corpses' (Isa. 14:19), 'holy ones' (Ps 16:3), 'ghosts' (Isa. 29:4) and 'healers' (Ps 88:11) (Bloch-Smith 1992:109). It is not unfamiliar to the Old Testament that 2 Sam 14:16 refers to the deceased as 'divine ones' (Lewis 1991:602, own emphasis):

Evidently the deceased in Ancient Israel, as elsewhere in the ancient Near east, could be referred to as אלתים (רפאים (as well). אליתים is no more a designation equating Samuel with Elohim than is ilu (in reference to the deceased) in the ancient Near Eastern texts mentioned above an equation with the high gods of the Canaanite, Mesopotamian, and Hettite pantheons. Again, this is simply a way of getting to the preternatural character of the deceased.

Apart from the reference in 1 Sam 28, where the spirit of Samuel is referred to as אלתים , אלתים 'ancestors' (that is 'divine ones'), e.g. the parallelism in Isa. 8:19-20a, equating מתים ('dead ones') with אלתים ('divine ones') (Lewis 1991:602); and the equation between the ('divine ones') and the ancestor statuettes (חדפים) in Gen 31:30 and Judge 18:24 (Van der Toorn 1990:210). ${ }^{8}$

In ancient Israel the deceased was 'gathered to his ancestors', a conventional phrase that derives from the fact that the body was placed in the family tomb (Mendenhall 1992:68).

7. A scene is defined as a narrative text which is to a high degree understandable in itself (Fokkelman 1981:9).

8. The idea of the people or the land of Israel as Yahweh's special possession are conveyed by the phrase a which exhibits a distinct national theology (Lewis 1991:600). 
The place where the dead maintained its shadowy existence was conceived of in spatial terms (Hooke 1965:237), often referred to as Sheol (Alexander 1986:43). Physical death did not, however, mark the end of the deceased's existence. A belief in the continued existence of the individual in the family grave after death formed part of the religion of ancient Israel throughout its history (Hooke 1965:236). The deceased were often consulted (Leviticus 19:31, Deuteronomy 18:11), and, some at least, apparently retained life-giving power (cf 2 Kings 13:11). Care of the dead, including the provision of nourishment (Deut 26:14), closely connected to other rites and rituals associated with the so called 'cult of the dead' (Snaith 1964:310; Bloch-Smith 1992:123), was the responsibility of the living descendants (Mendenhall 1992:72). In the grave the deceased was remembered by the family and continued to play an important role in the life of the family (Bloch-Smith 1992:122):

The dead were believed to continue living with benevolent and perhaps malevolent powers, therefore, it is not surprising that the living would want to appease the deceased, including providing nourishment.

The concern of the widow is therefore not merely the survival of her son, i.e. preventing the clan from 'taking' his life.

Such action taken by the clan would not only extinguish the 'coal' that is left behind, (i.e the remaining son), but, also, no one would be able to 'establish a name and a remainder' for the deceased husband, i.e. to maintain and continue the ancestral inheritance and secure the survival of the family, inclusive of the ancestor, on the ancestral land. Without a male descendant the name (identity) of the ancestor would eventually be forgotten from the face of the earth! The reaction of the widow in 2 Sam 14:7, 16 illustrates the interconnectedness between the land, the ancestor and the next of kin, specifically the son(s), who's responsibility it was to see to the proper burial of the deceased, and the 'keeping alive' of his name (Olson 1991:278):

The practice of ancestor veneration with its attendant sacrificial system is an ancient rite which facilitates wholeness.

The family's stake in 'immortality' was dependent upon the proper burial of the deceased in the family grave, and the maintenance of the family, including those in the grave, on the ancestral estate. The future of the widow, as well as the forefather (deceased husband) was dependent on the survival of the descendant. The condition of the deceased was, in a vague but significant way, connected with proper burial upon the ancestral land and with the continuation on that land of the dead's proper progeny. Thus the burial practices, customary law (i.e. protection of the widow/land) and concepts such as future (i.e. remembrance, also of those in the grave) and hope (i.e. descendants) ${ }^{9}$ form an important strategy of survival in the Old Testament.

\subsection{The importance of the ancestral estate.}

The term נהתלח ('Besitzanteil'/ possession) occurs rather frequently in the Hebrew text (BHS) (Jenni \& Westermann 1984:55). A variety of concepts, such as landed property, promise of the land, divine ownership and people as 'property' are being associated with the term (Lewis 1991:606). Old Testament scholarship, in general, regards the term as designating a) the land of Israel as being Yahweh's possession (Miller 1969:456; Hertzberg

9. Cf. Oosthuizen (1995:31-47) on future expectation in the Old Testament through generational continuity. 
1964:333); or b) the people of Israel as being Yahweh's special community, i.e. the covenant community (Lewis 1991:598). Although the term is common in the Hebrew Bible and used in a variety of grammatical constructions and contexts, the expression occurs only in 2 Sam 14:16 (Lewis 1991:597).

פוגנהלח (Noun, fem., sing., construct) with the prefix פר (preposition - 'from'), may be translated as 'from the portion of', or, '(away) from the inheritance of', and, as we have already seen, the 'divine ones', (Lewis 1991:600):

When one looks at the use of אלתים in the Hebrew Bible as well as the use of ilu in the cognate literature, another proposal presents itself, namely, that גלתלח אלתים refers to the ancestral estate.

The woman makes it quite clear that if the customary law be applied, and the go'el (cf 2 Sam 14:7,11,16) be allowed to kill her only remaining son, it would effect both her son and herself (Hertzberg 1964:333; Brichto 1973:23).

The effect of such action on the son, obviously, is death, and the possibility of not being buried in the family grave (Deut 21:22-23); but for the widow it maybe death for her as well (Sam 14:7,11), and indirectly, the loss of the ancestral heritage. Also, the welfare of the dead is somehow connected with the continuation of his descendants upon his inherited property (Brichto 1973:16). The continuity between generations was a reality, a grim reality for those who faced the possibility of losing their inheritance (Halpern 1991:59):

The Israelite inherited the house of his ancestors, the fields of his ancestors, the gods of his ancestors, and, in the end, the place of his ancestors' tomb.

The ancestral inheritance together with descendants were regarded as gifts from God and were intended to secure the future existence of the people in the presence of God. But, the clan wanted to revenge itself on the fratricidal murderer. The underlying motive of the kinsman was clear, by killing the male heir neither name nor remnant would be left to have claim over the ancestral property, which would then revert to the kinsman (Hertberg 1964:331; Lewis 1991:611). By its very nature the institution of go'el pits motives of kinship, loyalty and piety against enduring self-interest and selfishness (Brichto 1973:17). But the ancestral land was the condition upon which survival of the family depended. In the socio-economic history of ancient Israel, land was a fundamental means of production. In consequence, ownership of land formed the basis of wealth of the ancient Israelites (Mosala 1991:20). The ancestral estate was the property of the family, not to be alienated, it belonged to the dead ancestors and to their unborn descendants - it was a sine qua non for their stake in immortality (Brichto 1973:9).

Property was essentially a religious concept, i.e. a gift from God. The land, as gift from God so frequently attested in the Deuteronomistic History, was, ideally, to provide for an existence at peace, free from war and conflict (Miller 1969:457) and in covenant with God, who was the ultimate owner of all property. The ancestors received the land as a grant from God, and the veneration of the ancestors, the sense of their prior claim to the land and continuing vital interest in it must have been accommodated by and integrated with what became normative Israelite worship (Brichto 1973:11).

The issue is whether the quality of life appropriate to the Lord's anointed, and appropriate for the citizens of the kingdom, could be brought forth in this world (Wharton 1981:352). The anxiety of the widow in the story (2 Sam 13:39-14:33) is related to the idea that he who has left the land has lost contact with God. The possession of land was not merely a private affair, exclusively for the expansion of control and power (Grusemann 1992:258): 
Freiheit und Landbesitz konnen verlorengehen durch soziale Abhangigkeiten, durch Nichteinhalten der Gebote, aber auch durch die Macht des eigenen Konig $(17,16)$. Landbesitz und Freiheit der einzelnen und des ganzen Volkes hangen dabei auf das engste zusammen (own emphasis).

Access to resources (land) was as important as formal control over them (Flanagan 1988:31). Hence the concern of the widow that she, with her son, might lose the land, as well as control over the land.

\subsection{Conclusion}

Israel's experience of kingship was not a happy one (Munting 1986:214). With regard to David, the Biblical tradition contains various images of David, positive as well as negative (Deist 1986:99; Loader 1986:187; Wharton 1981:343). Underlying the account is the tension created by the chiefdom's pull towards the centralization of power and the opposite pull towards autonomy of the regional 'clan'/ village units (Tadmor 1982:245; Bellafontaine 1987:61). The basis of the tensions in the story was Israel's lack of enthusiasm for the Jerusalemite leadership (Flanagan 1988:238). The emergence of centralized leadership was an important motive in the formation of the presumed 'United Monarchy' (Flanagan 1981:58).

The translation of the term נתלח אלתים as referring to the ancestral estate makes perfect sense within the context of the process of 'displacement' of desperate power groups and corresponding 'ascendancy dominance' of centralized governance under David (Bellafontaine 1987:64). The traditional basis of Israelite society, namely, possession of land by the family, clan and tribe as a sacred trust (cf 2 Sam 20:1) came to be replaced by the person of the king. Through opting for the 'family' (widow) in spite of possible resentment of the intrusion of the state upon tribal independence David 'overruled' the tribal justice (contra 1 Kings 2:31), and proceeded with the gradual replacement of segmentary tribal structures (Tadmor 1982:247; Flanagan 1988:246).

The subsequent 'struggle' over the legitimacy of the rule of David, which remained an uncertain issue until the end of his career (Muntingh 1986:206), also found expression in the problem regarding the succession to the throne (Bright 1980:207; Vorster 1986:349) and demonstrates the existence of deepgoing tensions and divisions in society (Wittenberg 1986:356). The organization of society based upon concepts of tribal kinship and family property in land resisted integration with the monarchy (Neufeld 1960:39):

It is certain that parallel with the new royal administration, the old clan or local tribal councils survived even up to the time of the downfall of the kingdom of Judah. Its character had changed greatly; either it had been subordinated or it remained in a constant state of tug-of-war with the King.

As the text stands now, it communicates an anti-Davidic or David-critical message in a setting which questioned the legitimacy of the monarchy (Deist 1986:125) and accepted the monarchy only conditionally. By ignoring the family's obligation in the legal problem he faces, David was trying to sever the old ancestral and family ties, and tied to secure the relation of the individual (and the family) to the central authority instead of to the land. 


\section{In search of a Theologia Africana}

The relation between African culture and the Christian faith in South Africa can be regarded as a complicated interchange between aspects of African culture and religious ideas, belief and rituals with that of Christianity - a subject of continuing research. Despite the similarities and compatibilities between the Old Testament and African traditional religion (Dickson 1977:156; Mbiti 1986:26), which suggests a rather common experience of reality (Burden 1983:54; Mbiti 1986:27; Oosthuizen 1993:194), care must be taken not to oversimplify the relation between the Old Testament and Africa. Also important in our discussion, is the status of African traditional religions, specifically in view of the fact that over $70 \%$ of the South African population think of themselves as Christians and merely 20\% as belonging to Traditional religions (Hildebrandt 1987:268). Statistics cannot, however, reveal the strength of African traditional religion (Mbiti 1986:4). The starting-point for the discussion of Christianity and its relation to African life and thought concerns the role (and interpretation) of the Bible. The Bible is exerting a tremendous impact on the religious scene in Africa where a new form of Christianity is evolving due to, amongst others, the availability of the Bible in African languages (Mbiti 1986:30):

So began the demand of African society for spiritual independence from the religious imperialism of Western extra-biblical ideas.

Various approaches ${ }^{10}$ can be discerned in contemporary attempts to articulate faith and to interpret biblical texts in particular contexts (Wambutda 1980:29). Terms such as adaptation, incarnation, indigenisation, accommodation, and inculturation have been used to describe the assimilation and re-expression of the Christian message by the African, but contextualization seems to be the most popular at the moment. ${ }^{11}$ Notwithstanding the ongoing debate since the coining of the term 'contextualization' by Sholei Coe and Sharon Sapseziah in the early 70's (Cole 1984:3), no clear consensus has emerged as to its meaning (Swanepoel 1993:69). Generally speaking, a contextual approach has as its task the bringing of two contexts together, the context of the ancient text and the context of the modern reader (Padilla 1981:18):

The contextual approach ... recognizes both the role of the ancient world in shaping the original text and the role of today's world in conditioning the way contemporary readers are likely to 'hear' and understand the text.

The process of contextualization that the author is concerned with in this discussion occurs at the level of the interpretation of the Bible (Wimbush 1985:9; Taber 1987:33). De Villiers (1993:10) refers to the theoretical reflection concerning the role and the interpretation of the Bible in 'contextualization' as 'technical contextual theology'. A central issue in the theological debate is how we use the Bible. The text of the Bible, preferably in its original languages (Pauw 1994:22; Wambutda 1980:34), should function as source, or warrant, for the alleged contextual theology because that is the arena within which the argument is taking place (Wimbush 1985:14; Adam 1990:12; Human 1994:88). An African Christian theology can be developed when a essential link between

10. Bevans (1992:186) distinguishes the following models as theoretical approaches that attempt to articulate faith in particular contexts, i.e. the anthropological model, the translation model, the Praxis model, the semiotic model, the transcendental model and the synthetic model (Bevans 1992:186).

11. In its interpretation of the Biblical tradition all theology is contextual according to the extent in which the questions posed to the bible and the tradition are (co-)determined by the situation (Konig 1981:38). 
an African context and the Bible can be established (Bosman 1990:50; De Villiers 1993:21); and where the biblical is allowed to inform a particular African milieu (Wambutda 1980:29):

However, in the fervent search for an African Christian theology, one aspect which happens to be the most crucial in the whole enterprise and which seems to have hitherto remained illusive to it, is a properly biblically grounded reformulation of African thought from which a theology should naturally evolve, a point already hinted at.

Contextual theology is not, however, merely a practically orientated theology, contra Moila (1992:122), in favour of intellectual simplicity. African Theology, in its examination of the biblical text, needs an exegetical starting point, and African theology has just begun to develop this point of reference as one of its foundations.

A new appreciation of the Biblical text can emerge when Africa develops a way of reading the bible in a way that reflects the view-points and life concerns of African Christians (Mbiti 1986:53; Ukpong 1995:11). In establishing its own identity, African (Christian) theology needs to define methodologically or theoretically the interplay between the African context and the Bible, and how it is structured. In so doing, African Christianity can explain its existence not chiefly on account of social issues but also by theological propositions (Wimbush 1985:12).

However, acceptance of the Bible as Holy Scripture does not preclude critical engagement of it (Wimbush 1985:16). In contextual theology one can distinguish a 'critical task' as well as a 'creative task' (Moila 1992:119). Old Testament scholarship needs to develop models of reading the Bible creatively and more effectively in the South African (African) context. In developing such strategies one need not ignore the contributions of so-called Western approaches, i.e. historical criticism (Wimbush 1985:16; Deist 1992:311-331), as if it is dealing only with 'hypothetical pre-stage analysis' that would 'never experience a divine encounter' (sic!) on the presumption that contextual theology, in fact a black theological perspective (Abrahams 1994:252), is reading the texts synchronically which would mean that the interpreter is occupied, only then, with theological-exegetical issues! Synchronical and diachronical procedures are not mutually exclusive but can inform the reader at different levels in critical exegesis (Boorer 1989:205; Jonker 1993:111).

In this process of establishing the identity of an African Old Testament scholarship, our interpretation of the text should also not simply be an artificial 'Africanising' of the Old Testament, i.e giving it a 'black appearance' (De Villiers 1993:21) in order to redress the 'inferiority complex' (Deist 1992:312) evidenced by the lack of theological reflection on the Old Testament from an African perspective (Mbiti 1986:60):

...the so-called relevant theology being propagated in South Africa which is little more than a ready-made European theology turned into a consumption commodity for Africans.

The variety of approaches and interpretations need not prevent any African perspective from establishing it's own exegetical approach to evolve a more critical and creative way of reading and interpreting the biblical text (West 1993:4). Without doubt various approaches to a more 'effective' reading of the Old Testament in Africa regard themselves as 'contextual'. As far as the Old Testament is concerned, genuine dialogue is still to be achieved. Old Testament scholarship in Africa still has a long 
road to travel before freedom can be attained from bondage and enslavement to foreign scholarship. Care must be taken, however, not to develop just another (African) hermeneutical key which will again manipulate the interpretation of the Old Testament (Donovan 1978:vii):

Do not try to call them back to where you were, and do not try to call them to where you are, as beautiful as that place might seem to you. You must have the courage to go with them to a place that neither you nor they have ever been before.

The responses to the text by the African reader will only be appropriate if they turn out to be rationalizations of a reader's reception of the promptings of the text (Vorster 1986:352).

\section{Conclusion}

The purpose of this contribution was to give an explanation of some aspects of 2 Samuel 14, with specific reference to 2 Sam 14:7,16, from an African perspective. That is, by allowing aspects which are crucial to an African world-view such as the forefathers and the ancestral land, to interact in the process of interpretation. The similarity and compatibility of the Old Testament world with that of African is not a new phenomenon to Old Testament scholarship. Burden (1986:103) correctly pointed to features of cosmological, anthropological and temporal orientation that are compatible, at least at face value. Apart from similarity in the role of myth, ritual and wisdom as expression of experience (Burden 1983:63) there is also similarity ${ }^{12}$ in the way in which time and history is understood (Oosthuizen 1993: 194). Also in its views regarding the family and the ancestral land can we identify traits that suggests a similarity in world view.

Comparative studies, with emphasis on ritual and customary practices is however, despite its pedagogical importance, not enough (Dickson 1972:156, own emphasis):

Comparisons of religions always run the risk of sinking 'to the level of collecting dead insects or pressed flowers, which in the process lose all their colour and reality', particularly when those who undertake the comparison do not have any clear idea of their purpose in so doing.

Old Testament scholarship in South Africa will have to move on and get clarification on the direction in which it wants to go concerning, e.g. model of interaction / contextualization, hermeneutical foundations; exegetical tools - a thorough investigation of the biblical text. In this regard the similarities in world-view, concepts and rituals may function as a hermeneutical key to open up the text for an African audience, and result in a new perspective on the biblical text. A Christian African theology can only be developed where the biblical text is allowed to inform a particular African milieu (Wambutda 1980:29). Scientific investigation render possible a variety of readings of the text, none of which could ever pretend to give a final and full explanation. A plethora of questions remain unanswered in the ongoing discussion concerning the interpretation of the Old Testament in Africa, and of course, the passage under discussion. A very important question in this connection concerns the appropriateness of interpretation. The methods that we develop, creative and critical,

12. This does not mean that the Old Testament displays just one conception of history, or that Africa has but one uniform African perspective on history (Burden 1986:104). 
involve not only the theories about the ways texts are capable of having meaning but also techniques for producing fresh interpretations (De Villiers 1993:21):

To be able to articulate the Gospel in one's own context is more than a theological activity. It is a powerful act in which the powerless ones are empowered to think, speak and act for themselves, freed from enslavement and domination. It is in the end a restoration of human dignity.

An attempt is being made to illustrate that, when the context of the exegete is taken into account in the interpretation of the text, it can function in a creative way, and, as such, it can be conciliatory and redress a divided society, that through the oppressive system of apartheid was forced to live and think apart from one another. In honest cross-cultural communication, mutual enrichment is inevitable (Olson 1991:273). 


\section{BIBLIOGRAPHY}

Abrahams, SP 1994. A black Theological perspective on the Old Testament. OTE 7 (4), 244-253.

Ackroyd, PR 1981. The Succession Narrative (so-called). Interpretation XXXV (4), 383396.

Adam, AKM 1990. Biblical Theology and the problem of Modernity: Von Wederstrasse zu Sackgasse. Horizons in Biblical Theology: An International Dialogue, 12 (1), 1-18.

Alexander, A 1986. The Old Testament view of life after death. Themelios 11 (2), 41-46.

Bailey, LR 1979. Biblical Perspectives on Death. Philadelphia: Fortress Press.

Bellafontaine, E 1987. Customary Law and Chieftainship: Judicial aspects of 2 Samuel 14:4-21. JSOT 38,47-72.

Bevans, S 1985. Models of contextual Theology in Missiology: An International Review, Vol xiii (2), 185-202.

Bloch-Smith, E 1992. Judahite Burial Practices and Beliefs about, the dead. Sheffield: Sheffield Academic Press.

Boorer, S 1989. The importance of a Diachronic Approach: the case of Genesis-Kings. Catholic Biblical Quarterly 51 (2), 195 - 208.

Bosman, HL 1987. Vertellers van die Ou Testament. Kaapstad: Tafelberg Uitgewers.

Bosman, HL 1990. Tweede naïwiteit en Derde wereld: teologiese nadenke oor die ou Testamnet. Theologia Evangelica. Volume xxiii (no 2), 45-56.

Bosman, HL \& Gous IGP \& Spangenberg IJJ (eds) 1991. Plutocrats and Paupers. Wealth and property in the Old Testament. Pretoria: JL Van Schaik.

Brichto, HC 1973. Kin, Cult, Land and Afterlife - a Biblical complex. Hebrew Union College Annual (HUCA) 44,1-54.

Bright, J 1980. A History of Israel. London: SCM Press.

Brueggemann, WA 1972. On Trust and Freedom. A study of faith in the succession narrative. Interpretation 28, 3-19.

Burden, JJ 1983. Are Shem and Ham blood brothers? The relevance of the Old Testament to Africa. OTE 1, 49-72.

Burden, JJ 1986. World-view in interpreting the Old Testament in Africa. OTE 4,95-110.

Coats, GW 1981. Parable, Fable and Anecdote: Storytelling in the Succession Narrative. Interpretation $X X X V(4), 368-382$.

Cole, V 1984. How can we Africanize our faith: another look atthe contextualization of theollogy. East Africa Journal of Evangelical Theology. Vol. 3 (no. 2), 3-20.

Deist, FE et al 1981. Van Eden tot Rome. Pretoria: JL Van Schaik.

Deist, FE 1981. Van Sigem tot Jerusalem, pp 76-87, in Deist, FE et al Van Eden tot Rome. Pretoria: JL Van Schaik.

Deist, FE 1986. David: a man after God's heart? An investigation into the David character in the so-called succession narrative. OTWSA 27(1984) and OTWSA 28 (1985). Old Testament Essays: Pretoria.

Deist, FE 1992. South African Old Testament studies and the future. OTE NS 5(2), 311-331.

De Villiers, PGR 1993. The Bible and the struggle (for power). Scriptura 45, 1-28. 
Dickson, KA 1972. African Traditional Religions and the Bible. In E. Mveng \& RTZ Warblowsky (eds) The Jerusalem Congress on Black Africa and The Bible, 155-166.

Donovan, V 1978. Christianity rediscovered. Maryknoll, N.Y.: Orbis Books.

Flanagan, JW 1981. Chiefs in Israel. JSOT 20,47-73.

Flanagan, JW 1988. David's social drama. A hologram of Israel's Early Iron Age. Sheffield: Almond Press.

Fohrer, G 1968. Introduction to the Old Testament. London: SPCK Press.

Fokkelman, JP 1981. Narrative art and poetry in the books of Samuel: a full interpretation based on stylistic and structural analysis. Assen: Van Gorcum.

Grusemann, F 1992. Die Tora: Theologie und Sozialgeschichte des alttestamentlichen Gesetz. Munchen: Chr. Kaiser Verlag.

Gunn, DM 1976. Traditional composition in the 'succession narrative'. Vetus Testamentum 26, 214-229.

Baruch Halpern and Deborah W. Hobson (eds) 1991. Law and Ideology in monarchic Israel. Sheffield: JSOT Press.

Halpern, B 1991. Jerusalem and the lineages in the seventh Century BCE: kinship and the rise of individual moral liability, in Law and Ideology in monarchic Israel. Baruch Halpern and Deborah W. Hobson (eds), 1991, 11-107.

Hertzberg, HW 1964. 1 \& 2 Samuel. London: SCM Press.

Hildebrandt, J 1987. History of the Church in Africa. Achimota, Ghana, W. Africa: Africa Christian Press.

Hindson, EE 1984. The sociology of knowledge and biblical interpretation. Theologica Evangelica XVll, 2 (Junie), 33-39.

Hooke, SH 1965. Life after death: V. Israel and the After-life. Expository times 76 (8), 236239.

Hovland, TH 1993. The new paradigm of African Theology. Africa Theological Journal vol. 22 (No. 2), 91-106.

Human, D 1994. Reading the texts of the Bible: with illustrative reference to Psalm 25. Scriptura 49, 88-96.

Ishida, T (ed) 1982. Studies in the period of David and Solomon. Winona Lake: Eisenbrauns.

Jenni, E \& Westermann, C 1984. Theologisches Handworterbuch zum Alten Testament, Band 2. Munchen: Kaiser.

Jonker, L 1993. 'Text' in a multidimensional exegetical approach. Scriptura 46, 100-115.

Konig, A 1981. Contextual Theology. Theologia Evangelica 14(3), 37-43.

Kung, H 1986. Where is Christianity going? Paper presented at the 18th annual congress of the South African Missiological Society. Pretoria.

Kurewa, JWZ 1975. The meaning of African Theology. Journal of Theology for Southern Africa (11), 32-42.

Lewis, TJ 1991. The ancestral estate ( ) in 2 Samuel 14:16. Journal of Biblical Literature 110 (4), 597-612.

Mbiti, J 1970. Concepts of God in Africa. London: SPCK.

Mbiti, J 1986. Bible and Theology in African Christianity. Oxford: Oxford University press.

McCarter, P K 1981. 'Plots, True or False'. The Succession Narrative as Court Apologetic. 
Interpretation $X X X V(4), 355-367$.

Mendenhall, GE 1992. From witchcraft to justice: Death and afterlife in the Old Testament in H Obayashi (ed) Death and afterlife: Perspectives of world religions, 67-82.

Miller, P D 1969. The Gift of God. Interpretation. 23, 451-465.

Moila, MP 1992. What is contextual theology? Theologia Viatorum Supplement, 117-125.

Mosala, I 1991. Ownership or non-ownership of land forms the basis of wealth and property: A black theological perspective, in Plutocrats and Paupers, wealth and property in the Old Testament by Bosman, H L \& Gous I G P \& Spangenberg I J J (eds) 1991, 20-25.

Muntingh, LM 1886. The role of Joab in the succession narrative. OTWSA 27(1984) and OTWSA 28(1985). Old Testament Essays: Pretoria.

Mveng, E \& RTZ Warblowsky (eds) 1972. The Jerusalem Congress on Black Africa and The Bible

Neufeld, E 1960. The emergence of a Royal-urban society in Ancient Israel. Hebrew Union College Annual (HUCA) 31,31-53.

Nicholls, BJ 1979. Contextualization: a theology of Gospel and Culture. Downers Grove, Illinois: Intervarsity Press.

Nida, E \& CR Taber 1982. The theory and practice of translation. Leiden: EJ Brill.

Obayashi, H (ed) 1992. Death and afterlife: Perspectives of world religions. London: Praeger publishers.Oduyoye, MA 1991. The African family as a symbol of ecumenism. Ecumenical Review vol. 43 (no. 4), 465-478.

Ogbonnaya, AA 1993. Person as community: An African understanding of the person as an intra-psychic community. Africa Theological Journal vol. 22 (2), 117-129.

Olson, HS 1991. A Seamless Garment-African understanding of wholeness. Currents in Theology and Mission vol. 18 (no. 4), 273-281.

Oosthuizen, R 1993. African Experience of Time and its compatibility with the Old Testament view of Time as sugeested in the Genealogy of Genesis 5. OTE 6, 190-204.

Oosthuizen, R 1995. Future Expectation as Continuation of Life Coram Deo in the Old Testament through Generatinal Continuity. OTE 8(1): 31-47.

Orwell, G 1945. Animal Farm. Middlesex: Penguin Books.

Padilla, CR 1981. The interpreted Word: reflections on contextual hermeneutics. Themelios, 7 (1), 18-23.

Parrinder, E G 1962. African Traditional Religion. London: Sheldon Press.

Pauw, C M 1994. Theological education in Africa. Old Testament Essays 7 (4), 13-24).

Reinhartz, A 1993. Anonymity and Character in the Books of Samuel. Semeia 63, 117-141.

Snaith, N 1964. Justice and immortality. Scottish Journal of Theology. Vol 17 (no 1), 309-324.

Spangenberg, IJJ 1986. Who is the wise one in 2 Samuel 14:1-24? OTWSA 27(1984) and OTWSA 28(1985). Old Testament Essays: Pretoria.

Swanepoel, FA 1993. Popularising contextual theology. Scriptura 45 , 67-78.

Taber, CR 1987. A place in the sun. Liberation Theology in the Third world. London: SCM

Tadmor, H 1982. Traditional Institutions and the Monarchy: Social and Political tensions in the time of David and Solomon. In T Ishida (ed) 1982, 239-257.

Ukpong, JS 1995. Rereading the Bible with African Eyes. Journal of Theology for Southern 
Africa, vol 91, 3-14.

Van der Toorn, $\mathrm{K}$ 1990. The nature of the Biblical Teraphim in the light of cuineiform evidence. Catholic Biblical Quarterly 52, 203-222.

Van Deventer, WV 1985. Die Ned Geref Kerkfamilie as konkrete ontmoetingspunt tussen swart en wit in Suid-Afrika. NGTT XXVI (4),500-510.

Vorster, WS 1986. Readings, readers and the Succession Narrative. An essay on reception criticism. Old Testament Essays 1986, 339-353.

Vosloo, W 1995. One small step for Biblical Studies. the Growth of the SA Biblical Studies Society. Scriptura 54 (3), 177-188.

Vriezen, Th C 1948. De Compositie van de Samuel-boeken. Orientalia Neerlandica. A Volume of Oriental Studies, pp 167-186. Leiden: A.W. Sijthoff's Uitgewersmaatschappy N.V.

Wambutda, DN 1980. Hermeneutics and the search for Theologia Africana. Africa Theological Journal 9(2), 29-39.

Wesselius, JW 1991. De wijze vrouwen in 2 Samuel 14 en 20. Nederlands Theologisch Tijdschrift 45, 89-100.

West, G 1993. Engagement, criticality, and contextualization. Scriptura 11, 1-17

Wharton, JA 1981. A Plausible tale: Story and Theology in 11 Sam 9-20, 1 Kings 1-2. Interpretation vol XXXV (4), 341-345.

Wimbush, VL 1985. Biblical Historical Study as liberation: Toward an Afro-Christian Hermeneutic. The Journal of Religious Thought vol. 42 (no. 2), 9-21.

Wittenberg, GH 1986. Ideology critique in the succession narrative. Old Testament Essays 1986, 354-379. 